\title{
The Demise, Dissolution and Elimination of Religions
}

\author{
Michael Stausberg \\ Department of Archaeology, History, Cultural Studies and Religion (AHKR), \\ University of Bergen, Bergen, Norway \\ Michael.Stausberg@uib.no
}

\begin{abstract}
While it is generally acknowledged that religions can "die" or go "extinct," little research has been dedicated to the problem of the demise of religions. This text reviews earlier research on this topic and develops some reflections on two types of religion (ethnospecific and transcendental ones) and on the end of indigenous religions. The text stresses the importance of ruler conversions and indigenous agency in religion demise and transformation processes, introduces the category of "religiocide," and proposes some criteria for identifying "religion death." Finally, it introduces the articles of this special issue.
\end{abstract}

\section{Keywords}

demise of religions - dead religions - religiocide - Christianization

If historians of religions know one thing for sure, it is that religions and religious landscapes keep on changing. Examples even of dramatic or radical changes come easily to mind. This special issue goes one step further by raising the question: Can religious landscapes change to such an extent that religions (i.e., what actors and/or scholars classified as such) can be said to have vanished from the maps? The articles probe and discuss key factors, trajectories, and entailments of selected processes. 
The notion of "religion death" (de Jong 2016) or the "demise of religions" (Untergang von Religionen; Zinser 1986) is acknowledged if we, for example, speak of extinct or dead religions - religions that have been widely attested in sources but that are no longer in existence. Jonathan Z. Smith, always the spirited eccentric, said in an interview with a Chicago student magazine: "I specialized in religions that are dead, which has the great advantage that nobody talks back. No one says, 'That's not what I heard last Sunday!' Everybody's dead" (Sinhababu 2008). In 1982, Smith had famously claimed "there is no data for religion. Religion is solely the creation of the scholar's study" (Smith 1982, xi). This remark has been the subject of extensive exegesis, but it cannot be overlooked that his caution concerning the overall category of religion notwithstanding, Smith found it unproblematic to speak of "religions" and he considered it an advantage that the data for dead religions is less in flux than data for contemporary ones, where practitioners are alive, speak back, and keep on modifying their religions even while we study them. So-called critical approaches to religion have gone beyond Smith and concluded that there is no data for religions. ${ }^{1}$ Removing religion from the toolbox signals a second-order elimination of religion; data remains, but it allegedly does not count "for religions."

\section{2}

\section{Questions}

Even if one, like Smith, does not subscribe to this kind of form of eliminativism, it is clear that speaking of dead or extinct religions is an act of imagination, classification, and storytelling that raises a number of theoretical questions. To begin with, is what we pronounce as dead just an arbitrarily selected segment of a culture or is there any theoretical coherence to it? And what kind of entity is religion so that it could cease to exist? Or: What kind of basic metaphor (grounded in different theoretic models) do we use when speaking of religions and how would we then describe their going out of existence? Do we perceive religions as organisms, so that they could "die"? Or as systems, so that they would "disintegrate"? As things, so they would "liquify"? As paths, so they would "end"? As clumps, so they would "dissolve"? As flows, so they would "disperse"? Or as building blocks, so they would "destabilize" or "collapse"?

1 See Schilbrack 2010 for a discussion and Engler 2016 for different takes on the "critical" project.

2 Religion as superorganism: Wilson 2002; as system: Luhmann 1977; as building block and thing: Taves 2009; as clump: Alles 2012; as flow: Tweed 2006. Could we also speak of cases 
Next, turning to the data: How do we know? Given that history is mostly written by "winners," "losers" are often left without a voice and their representations tend to be overshadowed by distortions. Is the absence of attested sources for a religion enough to stipulate its disappearance? Further: Why do we ask? Since when are we in the business of issuing death verdicts and what interest could we have in this business? What kind of memory-work is at play here? In the long run, if "nothing is ever lost," as an influential evolutionary theorist claims (Bellah 2011), is the question ultimately relevant at all? ${ }^{3}$ Moreover, is it the supposed endpoint or the process leading to it that are of interest? Finally: Is religion death irreversible, or can extinct religions (provided that enough information is stored externally) be revived? And if so, can and should we judge the authenticity of such projects or accept all such claims uncritically, even if the meaning of such a religion would be very different? Last but not least, is religion death easier or more difficult to diagnose than, for example, language death, or the downfall of empires? Is some aspect of a religion to be attested in a later age a mere "survival" or does it justify the claim that the former religion has remained alive - and how many such fragments would be needed for such a claim to be made plausibly? And what kind of theories of religion would promise to address such issues?

These are the kinds of questions we discussed as part of the research group "The Demise of Religions" at the Centre for Advanced Study (CAS) at the Norwegian Academy of Science and Letters in Oslo during the academic year 2018/19. Against our discipline's fascination with origins and beginnings (Gilhus 2014), this project shifted focus onto the question of ends and endings;

for a "collapse" of religion? Diamond defines collapse as "a drastic decrease in human population size and/or political/economic/social complexity, over a considerable area, for an extended time" (2005: 3). Religious collapse could then mean a drastic decrease in numbers of believers; yet, as far as I can see, any such possible cases do not fit Diamond's pattern. For a discussion, see also Arp-Neumann 2021 (this issue).

3 The phrasing invites misunderstandings; as Bellah explained in interviews, the message he wanted to convey with this formula was quite the opposite of what it could mean on the surface (and as read by de Jong 2016): “Nothing is ever lost' means that what we are now goes all the way back through natural history. We are biological organisms and not simply computerized brains. By focusing totally on the present, thinking only about science and computers, and forgetting four billion years of life on this planet, we are losing perspective on who and what we are" (Schneider 2011; Dreher 2011). In other words, the phrase was meant to affirm accumulation rather than to deny loss. A reader of this article suggested adding that Bellah's formula clearly refers to "anything of importance"; this, however, risks being self-confirming: if something has not been lost, it obviously was of importance, if something got lost, it obviously was not important.

4 The group assembled the following scholars: Janne Arp-Neumann, Erica Baffelli, Jan Bremmer, Carole Cusack, Laura Feldt, Albert de Jong, James Lewis, Richard Lim, Joel Robbins, Jörg Rüpke, Michael Stausberg, Olof Sundqvist, and Stuart Wright. The late Liselotte 
from birth to death, if one would opt for that metaphor. While the fact of there being dead or extinct religions is readily acknowledged (see above), there is a glaring absence of literature dealing with this issue in a general manner.

\section{Dealing with Demises: A Brief Research History}

Contributions dealing with the issue in question can be counted on the fingers of one hand. A review of these will serve as an entry point to the debate. In 1921, James Bissett Pratt, a student of William James, published a short programmatic piece on "Why Do Religions Die." Pratt considered nine or ten historical cases as relevant: "the death of the Egyptian religion, the Babylonian, the Greek, the Roman, the Teutonic, the Celt, ... the disappearance of Buddhism from India and of Zoroastrianism from Persia, and possibly the present decline of Jainism and the secularization of Shinto." He finds it "plain that some religions die from violence while others fall prey to internal and more subtle evils.". He also reckoned with "hostile missionary activity," but the two sets of factors seem to belong together as he finds that "long before there was any violent propaganda against them they seem to have been in something approximating a moribund condition"; thus, this raises "the question of religious pathology" (Pratt 1921: 77). The idea of such a decadence can seem intuitive and it is still found in more recent literature (see, e.g., Hubai 2001 for the case of pre-Christian Egyptian religion). The 1984 annual meeting of the German Association for the History/Study of Religion (the national memberorganization of the IAHR) was dedicated to the demise of religions (Untergang von Religionen). The papers were published as an edited volume two years later (Zinser 1986). In addition to many case studies covering a wide array of time and space - from the ancient world to the present, from Europe to Indonesia the volume has a substantial introductory essay by Carsten Colpe, written in his inimitable complex style. In a uniquely learned and reflective manner, Colpe raises a number of relevant questions. I can only pick some examples here. For example, he notes that addressing the issue of demise would necessitate a method to determine a historical essence of religions, which we do not have (or do not want to have) and the possibility to measure religious vitality, which is largely avoided. Regarding a potential definition of demise, Colpe asks whether this would imply a complete disappearance or be more like the sinking of a ship, which then remains invisible like a wreck on the seabed?

Frisk joined the team as a visiting guest. Jens Braarvig was a permanent guest. See Stausberg, Wright, and Cusack 2020 for an outcome of the project for contemporary religions. 
Religions can be practiced in secrecy. While physical extermination presents the clearest case of disappearance (Verschwinden), Colpe proposes that religions can be considered as institutionalized and organized complexes that can be smashed, but also practices like intermarriage can result in destroying the core of religions. Reflecting on the meaning of demise, Colpe suggests, would make us rethink religion in terms of stability and persistence, resilience, recurrence or ability to regenerate, its fragility, and its willingness to retreat. Colpe's reflections cannot be summarized, and his essay does not advance any kind of thesis (Colpe 1986). In its radical reflexivity and openness, it represents an example of inquiries in the humanities - its lack of a clear thesis is at the same time frustrating reading for others. Yet, research of this type always remains unfinished business.

Almost 30 years passed before the next substantial contribution appeared. It came from an anthropologist of Christianity, Joel Robbins. Although based on fieldwork among one relatively small group of people living on a remote island in the West Sepik Province of Papua New Guinea, Robbins drew out wider implications. Even though his focus is on the how, not the why of this process, the case, as he recounts it, resonates with Pratt's article insofar as he found that the traditional religion had faced severe difficulties before the eventual onset of the collective conversion of the group following a Christian revival. The second step in his analysis focuses on "the material erasure of the traditional religion" in the sense of "the careful, frequently almost ritualized, abandonment of the material supports of traditional religious practice" (Robbins 2014: 7). As this erasure is not the work of "foreigners" but of the converts themselves, the people are both subjects and objects of this change. The third step, or dimension, of this process is what Robbins calls "replacement and displacement" of traditional religious ideas and practices, whereby Christian ideas and practices substitute for pre-Christian ones (replacement) or where traditional ideas and practices were delegated to a less important role and reinterpreted in the process (displacement) (9-10). Given its small population size and isolated location the case studied by Robbins is by no means exemplary or even typical, but he proposed a suggestive terminology and his focus on the indigenous agency in the process of demise - rather than seeing this, for example, as the work of conquerors or missionaries, or kings - was refreshing. ${ }^{5}$

5 The article was followed by some insightful responses, for example by Aparecida Vilaça on the Brazilian Wari' who "were never concerned with the 'persistence' of their 'religion"” (Vilaça 2014: 16), as for them "their religion was not made to last" (18). She speaks of "eclipse" rather than disappearance of their religion, and finds that for them the adoption of Christianity was not a path of no return (17). 
In 2016, the Dutch historian of ancient and Middle Eastern religions Albert $\mathrm{Ab})$ de Jong published "The Disintegration and Death of Religions," the landmark study of our issue (de Jong 2016). De Jong is a leading scholar of Zoroastrianism, a religion that has seen a clear demographic decline during recent decades to the extent that some adherents fear its eventual extinction, so that it could be called an endangered religion. ${ }^{6}$ This may have sensitized de Jong to the topic. He calls for an act of "academic courage," namely to establish some sort of "distinctiveness for concrete religious traditions" as a kind of historiographical compass that can allow the measuring of degrees of disappearance and presence. This raises the question, not addressed by de Jong, of insider vs. outsider ascriptions: for example, considering the radical change brought about by the religious transformation in post-Vedic Indian religious history, scholars can speak of the disappearance of a specific religion whereas Hindus consider the Rig-Veda as foundational texts for their religion. This is only one of many examples for the observation that religions float on seas of debris of earlier formations, just like many languages rest on earlier stages that are considered defunct.

De Jong draws on the well-established field of endangered languages and language death in linguistics to explore a descriptive vocabulary ("relexification," "reanalysis," "dialect levelling," "attrition," "erosion") and seek for analogs in the religious realm. Just as languages that no longer have any active speakers are classified as extinct, "Religion death ... can be defined as the process resulting in the absence of believers or practitioners" (de Jong 2016: 652). This presupposes clear boundaries around these categories; does reading or narrating Greek myths and depicting Greek deities in early modern Europe amount to some sort of belief and practice of pre-Christian religion? ${ }^{7}$ Just as in languages, religion death or disintegration can be set in motion by exogeneous and/or endogenous factors (or evolutionary selection mechanisms, if one opts for that theoretical framework). ${ }^{8}$

6 For reflections on the category of "endangered religions," see Stausberg 2019.

7 See Stausberg 2009 for different claims and interpretative models (such as Paganism, Neoplatonism, Christian assimilation, pagan dreams, polytheism, eclecticism, syncretism, pluralism, patchwork).

8 This distinction has been used for cases from the modern and contemporary periods; see Wilson 1987; Miller 2010; Wright, Stausberg, and Cusack 2020. In addition, one can distinguish between push and pull factors, e.g., Paldam 2017. 
De Jong offers another useful distinction: religions that do not thematize their existence as religions, and those that do - we could call the former implicit, the latter explicit religions. The former he refers to as "ethno-specific" religions. These religions disappear with the people practicing them or the political structures sustaining them: de Jong's examples are ancient Hurrian, Hittite, and Elamite religion. We could also mention the Etruscans as a case, where an ingredient of religious practice (namely haruspicy) has been adopted by another people and thereby survived in a different historical setting - to the extent that it was considered properly Roman by classical authors (Montero Herrero and de Vera 2017: 339). ${ }^{9}$ In a later part of his chapter, de Jong speaks of "community religions" - in contrast to "religious communities" - as the supposedly original form of religion; $;^{10}$ most such religions (which others might call indigenous religions) "have died out together with the societies to which they belonged, and it is only with the concomitant rise of anthropology and intense missionary activity in the nineteenth century that they have begun to be recorded and explored" (de Jong 2016: 655). It is only in increasingly peripheral, marginal, and isolated spots on earth that this kind of religion has survived.

The other form of religions is the self-conscious, explicit, secondary, or transcendent religions. In my understanding, for the present purpose, these can be distinguished by the following six interrelated features. One, these religions have developed explicit names and proclamatory self-identifications for themselves that go beyond the people to which they belong and that conceptualize them as ideal and normative values that require commitment and which are to be disseminated. Second, they envision some sort of religious community (e.g., "church," ummah, sangha). Third, their proclamatory and communal distinctiveness was developed in contradistinction to others. Fourth, while these religions are always fully contextualized, their ambitions go beyond any single societal and historical context - for example, while Egypt became predominantly Christian and Christianity absorbed many features of Egyptian religious culture (Frankfurter 2018), Christianity was not considered to be an exclusively Egyptian affair, as learned Egyptian Christians were aware of the existence of versions of Christianity in other countries. Fifth, these religions have developed teachings and practices that claim a superior, transcendent,

$9 \quad$ See Rollinger 2017 for the Ancient Near Eastern roots.

10 This recalls the distinction between primary and secondary religions; see Wagner 2006; Krech 2012. 
and universal form of truth (typically deposited in scriptures). Sixth, these religions have developed stable religion-specific institutional roles, ranks, and offices held by qualified persons permanently or during long periods of time. ${ }^{11}$

\section{A Mass Extinction of Religions? Different Trajectories of Diversity}

The prototypical examples of the explicit religions are Buddhism, Christianity, and Islam. De Jong refers to the latter two only. Not only were Christianity and Islam more successful than Buddhism in spread and reproduction rates, but, in de Jong's words, their respective expansions were

accompanied by what can only be described as a mass extinction of religions. Although it took an extensive period of time, Christianity eventually made extinct all religions of Europe, and most religions of the Near East west of the Euphrates, with the sole exception of Judaism. Likewise, Islam removed much of Christianity, most of Zoroastrianism (all of it in Central Asia), and all of whatever had remained of the community religions of the Near and Middle East, with the exception of those of the Jews, Samaritans, and Mandaeans. ${ }^{12}$

DE JONG 2016: 657

While the pre-Christian religions of the areas mentioned showed a remarkable degree of diversity - in particular as few of them had hierarchical forms of governance - their extinction did not quench religious plurality as such. Christianity and Islam existed in a bewildering variety of forms. Taking the language analogy, diversity, competition, conflict, and convivence have shifted from the analytic level of languages to that of dialects; even if one language has a virtual monopoly, it is spoken, written, and transmitted in a range of dialects, and just as speakers of dialects can have an aversion toward other

11 Sundqvist 2021 (this issue) discusses a related typology as does Feldt 2020.

12 Many pre-Buddhist religious traditions of Asia have dissolved into Buddhism - similar to the absorption of pre-Christian traditions in different parts of the world - with the difference that Buddhism did not create encompassing residual categories for others ("pagans") and that Buddhists did not prohibit or actively suppress or annihilate the traditions they met. It is often said that Buddhism has died out in India, its country of origin, by around the 13th century; for a review of common explanations, see Berkwitz 2010: 139-142; however, Berkwitz speaks of Buddhism's "alleged disappearance" and observes that, "contrary to conventional wisdom, Buddhism did not wholly die out in the Indian subcontinent by the thirteenth century" (142). 
dialects (while other languages can seem less threatening), different factions of Christianity and Islam were fighting each other vehemently. The hegemonic status of (some versions of) Christianity and Islam vis-à-vis other religions, brutal campaigns of violence notwithstanding, must not be confused with their internal coherence and homogeneity.

In the Christian sphere, already in the early periods of its enjoying imperial support, campaigns against dissenting Christians were of far greater concern than the ever diminishing and marginal(ized) presence of non-Christians. Consider the diverse ecclesiastical and confessional splits of Christendom. The zeal to spread Christianity and to abolish non-Christian forms of religion was not limited to the Catholic variety. Take the Lule Saami: Håkan Rydving has documented the activities of the Protestant clergy aimed at the destruction of the Saami religion: "threats, punishments and sacrileges, more than anything else ... deculturated the Lule Saami from their indigenous religious customs" (Rydving 1995: 165).

In the orbit of Islam, as de Jong (2016:658) points out, there is a tradition of religious groups such as the Alevis or the Druzes whose Islamic identity is a matter of dispute, or who have originated on the margins of Islam (the Yezidis). One important contextual difference between Buddhism and Christianity on the one hand and Islam on the other was that Buddhism and Christianity were adopted and propagated by the dynastical leadership of established empires, while the rise of Islam was concurrent with the surprising rise of a completely new imperial political structure in the form of the Caliphates.

Manichaeism, a religion that shared some typological features with Buddhism and Christianity, was adopted by a Uyghur khagan in $763 \mathrm{CE}$ but after the downfall of the Khaganate in 840 its successors turned to Buddhism. Some Uyghur refugees established the kingdom of Qocho (or Kocho) in Turfan. During several centuries, Manichaeism received some support. Manichaeism's failure to secure the lasting patronage of a political empire, state, or dynasty may have been one factor facilitating its ultimate disappearance. The religion, which formed hybrid connections to Christianity and Buddhism, was suppressed in the Roman and the Chinese Empires; in the Mediterranean world it disappeared from the sources in the 6th century, in China only a millennium later (Klimkeit 1986; Lim 2019).

Typologically, the pre-Christian religions of Europe and the Middle East can be compared to the indigenous (community) religions that European Christian 
and later Muslim explorers, traders, missionaries, and administrators encountered in the processes of their worldwide expansion (Cusack 2013). In many parts of the world, as pointed out by de Jong, this has resulted in a global wave of disappearance, dissolution, extinction, or transformation of these religions. Religions, of course, are only the tip of the iceberg of the massive destruction, extermination, disappearance, fading away, loss of cultures and societies all around the world as a result of white European settler expansion, colonialism, imperialism, capitalism, militarization, and globalization. An awareness of this process has spread since the 183 os and was one of the reasons for the emergence and relevance of social anthropology (Gruber 1970) - including studies of language death.

The case studied by Robbins (see above) is just one among thousands of examples of the end of an indigenous religious tradition. A 2010 report by the Pew Research Center's Forum of Religion \& Public Life showed the massive religious change in sub-Saharan Africa during the 2oth century. In 1900, Christianity and Islam were small minorities of 9 and 14 percent of the population respectively, totaling less than a quarter of the population; by 2000 the number of adherents of what is classified as traditional African religions was down to 13 percent, while Christianity now had a population share of 57 percent, Islam 29 percent (Pew 2010). Similar developments have occurred in other parts of the world. For example, during the past two centuries the vast majority of Pacific islanders have become Christians. A macro-study of the relatively well-documented adoption of Christianity among most Austronesian societies over the past two centuries has shown that the process that resulted in at least half of the population of these societies becoming Christians sometimes took just one year, but sometimes it went on over two centuries; the median range of years for this process was 25 and the mean was 30 years (Watts et al. 2018: 56o). ${ }^{13}$ Raymond Firth's long-term fieldwork on the island of Tikopia in the Pacific Ocean provides a case study of the disappearance of an indigenous religion and its replacement by a form of Christianity. Christianity first came to Tikopia in 1858; when Firth arrived in the late 1920s, Christians and adherents of the old ways coexisted as neither of the two groups markedly outperformed the other. But the situation had changed when Firth returned in the early 195 os and found "paganism," as he calls it,

13 At the same time, the authors state: "In Austronesian-speaking cultures, the conversion process occurred remarkably rapidly, with the majority of cultures sampled taking less than 30 years to convert." (Watts et al. 2018: $5_{60}$ ). 
in a critical state. The adherents of the "things of the chiefs" saw themselves as a diminishing band, dedicated to the performance of the ancient rites, but encircled and threatened by a progressively encroaching rival.... it was losing adherents constantly to Christianity and maintaining its systematic rites only with difficulty.

FIRTH 1970: 384

The backbone of the supremacy of the Christians, as Firth describes this development, was their regular external "reinforcement" from beyond the island. The process of the people of Tikopia abandoning their traditional ways was accelerated by the outbreak of a severe epidemic in 1956. The death of many practitioners who could not be replaced in numbers and in time to maintain a sufficient degree of expertise rendered the old religion no longer operative. As a result, remaining persons with religious authority "bade farewell to their pagan religious relationships" (Firth 1970: 391) before they let themselves be baptized. Obviously, without contact with Christianity the former religion would not have disappeared - and that is the case with many missionary encounters - even though the eventual demise of Tikopia's indigenous religion took around a century to be concluded. Indeed, it even needed an epidemic to seal its fate. Diseases that decimated indigenous populations - or immunity to such diseases manifested by propagandists of incoming religions - were as powerful a weapon of assumed Christian supremacy as novel economic, material, medical, and social resources.

In contrast to Firth's attention to the eventual disappearance of the preChristian religion of Tikopia, other ethnographic studies have sought to capture the pre-Christian religious worlds of certain people. Examples of this kind of "memory ethnography" (Rothstein 2016: 77) or "salvage ethnography" (Gruber 1970) include, to just take two Danish examples, Torben Monberg's (1991) work on Bellona Island in the Solomon Islands, whose gods had fled to their heavenly abodes (where they still reside) after having been outperformed by the Christian god in a dramatic fight in 1938 (Monberg 1962), ${ }^{14}$ and Mikael Rothstein's (2016) systematic portrayal of the (disappearing) religious world of the Penan of Borneo; besides the timber processing industry and irresponsible politicians, Rothstein holds the Christian missionaries responsible for cultural destruction. They did this by setting up a religious monopoly, demonizing the traditional religion and introducing a form of religion that Rothstein finds

14 When the first Christian missionaries arrived in 1910, they were promptly killed. As an alternative strategy, people from the island were taken to mission stations (Monberg 1962). 
incompatible with the needs of the Penans' ecological and social world. As if that was not enough, he claims that this religion promotes the collapse of their culture. From this perspective, missionaries are not only agents of change but also of planned religious extermination. However, as Rothstein's account also shows, to be effective, missionaries do not operate in isolation but are backed up by other powers, mainly political and economic ones. Yet, we should be careful not to overgeneralize; for example, some missionaries have supported indigenous people in their struggle against oppressors or provided services such as healthcare, food, and education - cost-benefit analyses of this type are difficult to establish, and should they be possible at all results might vary from case to case. Furthermore, the kind of incompatibility between forms of Christianity and indigenous cultures stipulated by Rothstein for the Penan of Borneo can probably not be generalized - especially if changes in missionary strategies are taken into account (see, e.g., Gallaher 2007). Moreover, while missionaries are often imagined to be agents of foreign interests and powers and are backed by foreign money, as Christianity spread it has become indigenized and so have its proselytizers. The above-cited macro-study of conversion to Christianity in Austronesian societies has shown that Austronesian people themselves became the main actors of spreading Christianity once that religion had first been established (Watts et al. 2018: 561) - as is also demonstrated in the case studied by Robbins.

Scholars like Monberg and Rothstein have sought to present an emphatic picture of the intact, precontact religion of "their" peoples. They search for purity rather than contamination. However, not all precontact religious formations have become extinct. In many cases one can observe surprising tendencies of resilience, rarely however do we find deliberate programs of strategic persistence, like in Second Temple Judaism (Weitzman 2005). There are various forms of adaptations and transformations, or even some degrees of revitalizations (such as in the case of the Chumash of Southern California, see Paldam 2017). This, of course, requires memory or memorialization of the former religion. Bellah's mantra "nothing is ever lost" could be adapted to "not everything is lost (forever)." There are various forms of acculturation, assimilation, and amalgamation; Christianity and Islam have been indigenized and indigenous religions have taken on features of Christianity or Islam, while others have been redesigned to fit models of "legitimate" religions, that is, religions that fulfill criteria imposed by governments to be accepted as "religions" (see, e.g., Kohl 1986 on Islam, Christianity, and Aluk to Dolo in Indonesia). Moreover, along with its spread, Christianity has changed dynamically and radically (see, for Oceania, Ernst 2012) to an extent that makes general typological dichotomies between indigenous religions and Christianity problematic. Last but not least, 
while ideas of radical rupture with the past reflect certain tropes of evangelical and Pentecostal Christian discourses (see, e.g., Meyer 1998; Engelke 2010), this should not obscure a careful analysis of potential continuities.

\section{7}

\section{Ruler Conversions}

In the Pacific region, the success of Christianity was greatly enhanced by the conversion of Pomare II of Tahiti and similarly of political leaders in Hawaii and Tonga. Winning over political leaders ("top-down") rather than spreading the religion through the general population ("bottom-up") is an established strategy of proselytization. It is successful insofar as it can be shown, for instance, that "cultures with political organization were faster to convert to Christianity" in Austronesian societies (Watts et al. 2018: 560). Ruler conversion has, since the days of Aśoka and Constantine, been the most effective model through which Buddhism and Christianity eventually became dominant religions in the Mauryan and Roman empires respectively. For the case of Islam, ruler conversions were important in the spread of the religion through subSaharan Africa and maritime Southeast Asia (Strathern 2017). Initially often achieved after successful healing and victory in battle, adherence to the new religion could then serve as a consolidation or even extension of power. While it could be expected that religious protagonists or specialists of the extant religion oppose such moves - and that has been widely attested - Alan Strathern points out that there are many exceptions to this assumed rule; for example, African prophets that advised rulers to give missionaries a hearing, or even high priests acting as "facilitators" of ruler conversions (Strathern 2019: 281). In many cases, the absence of fixed doctrines and institutional constraints put religious leaders at liberty to explore new paths, or to incorporate and adapt new techniques, symbols, and ideas. On the other hand, their limited institutional independence curtailed their agency so that it could be a risky business to oppose chieftains or rulers. In many cases it was wise for them to join their chieftains or rulers on the new paths, or at least not to resist innovation as a matter of principle: "Indeed, the material on the conversion of the high chiefs and kings of Oceania is most explicit on the way that important priests acted in partnership with rulers (or even as initiators) in the elite conversion dynamic" (284). Moreover, it is not appropriate to project ideas on watertight division of labor between "kings" and "priests" on the historical sources: "kings" often had religious functions and were ascribed a semidivine status, they had religious powers, and threw in religious performances or (claimed) experiences such as visions or dreams into the process (282). The conversion of rulers was an 
important trigger for the spread of self-styled explicit religions like Buddhism, Christianity, and - at a later stage - Islam, but it was no automatism; typically, it would take at least another generation for the new religion to gain a solid foothold. As Strathern shows, new transcendentalist or metaphysical cognitive models and explanatory schemes that were able to integrate and at the same time outperform traditional forms of validation were put into place; religious affairs were reorganized into a sphere of religion (see also Rüpke 2021 [this issue]).

\section{$8 \quad$ Religiocides}

The power balance on the religious fields has undergone quite a dramatic change during the 2oth century when freedom of religion has become the norm and religion is in an influential model considered a private matter. Even if democratically elected heads of states may experience individual conversions, their own adoption of a new religion would probably not have the snowball effect of a change of religion in the general population as was the case with ruler conversions sketched above. Even in the 2oth century, however, many states - in particular those enshrining Islam, privileging Christianity, or professing atheism - practice various forms of religious discrimination (see Fox 2016, 2020) so that minority religions are under pressure. As pointed out by de Jong, the fate of religious diversity has reversed in the Middle East and Europe during the modern age: "Europe is becoming increasingly diverse in religious terms ... and the Middle East is quickly losing its previous high level of diversity" (2016: 658). The brutal crimes committed by Is (ISIL, ISIS, or Da'esh) against the Yezidis, the Druze, Shiites, non-Salafi Sunnis, and Christians clearly aimed at extermination of all forms of religion that did not match their own idiosyncratic version of Salafi jihadism..$^{15}$ This is a clear case of religiocide, a concept constructed in parallel to genocide. The latter has been defined officially in article 2 of the Convention on the Prevention and Punishment of the Crime of Genocide (1948) as:

any of the following acts committed with intent to destroy, in whole or in part, a national, ethnical, racial or religious group, as such: killing

15 Is even destroyed monuments of long-since defunct religions ("cultural heritage"). Is publications gave a theological justification for these acts (against "idolatry," "polytheism"), which also served to index the rejection of colonialism, nationalism, and modern values; see Isakhan and Gonzáles Zarandona 2018. 
members of the group; causing serious bodily or mental harm to members of the group; deliberately inflicting on the group conditions of life calculated to bring about its physical destruction in whole or in part; imposing measures intended to prevent births within the group; [and] forcibly transferring children of the group to another group.

UN General Assembly 1948

While this definition covers crimes against "religious groups," religiocide, which is not a legal but an analytical term, sets the focus on religions to single out cases where the religious rather than other features of identity are the prime markers of identification of the victims. In this sense, the holocaust (Shoah) was not a direct religiocide, but one by implication as the target group was the Jewish people ("race"), which included atheist, nonpracticing, and nonbelieving Jews and Jews who had converted to other religions. Yet, the potential extermination of the Jewish people would also have put an end to Judaism as a living religion. Just like genocide, a religiocide refers to actions undertaken by outsiders. For this reason, if people decide to phase out their own religion - as in the case analyzed by Robbins - we would not speak of them committing a religiocide, even if missionaries might have religiocidal intentions by implication, insofar as they aim to replace one religion by another one and thereby actively promote or passively accept the dissolution of another religion.

The massacres against the Armenians from 1894 to 1924 in the Ottoman Empire and the early Turkish Republic were a case of religiocide as it was their religion that served as the primary target of identification. Already in 1892, the Yezidis had been urged to abandon their religion by converting to either Christianity or Islam; when they did not do so they became victims of punitive expeditions, mass rape, massacres, pillage, and their central sanctuary at Lalish was raided and put under Muslim control (Savucu 2016: 68-69). There is a continuity from the Ottoman religiocide to the one committed by Is (Cheterian 2019). At present, the Muslim population in the Xinjiang Uyghur Autonomous Region of the People's Republic of China is reportedly treated in a manner that seems to conform to many of the criteria for genocide listed above; the state's aggressive acts - including forced sterilization - are directed against the Uyghurs as a people and their culture, but the campaign also has features of a religiocide. The government refers to the Uyghurs' Islamic identity as a legitimation as it is claimed to act against "religious extremism." According to many reports, thousands of mosques and shrines have been demolished, damaged, or made inaccessible in recent years.

While killing all adherents of a religion would certainly constitute the most radical form of religiocide, do we have evidence that such a bloodthirsty 
strategy has ever succeeded in its lethal agenda? As Laura Feldt (2021) suggests in this issue, we can also speak of "imagined" religiocides for narratives of total "religion demolition" that probably did not refer to real events but were imaginary visions, fictive and strategic narratives told for specific agendas (see below), as the negative side of a positive identity formation (Feldt 2020).

\section{$9 \quad$ Criteria for Extinction}

How could one conceive of or even "measure" the question of the demise of a religion from a theoretical rather than from a demographical or numerical point of view? Among questions that are commonly addressed by theories of religion (see Stausberg 2009; Stausberg and Engler 2016), relevant criteria could revolve around the effects, functions, and structure of a religion. A comparison with money is helpful in this regard. If money does not allow one to make transactions (to buy or to sell things), it is no longer effective; it has lost its value. Similarly, if certain acts are still known but no longer expected to achieve blessing or healing, to pacify or to invoke deities into action, if ancestors or deities are no longer expected to intervene even if one can still talk about them and know their names, this sort of communication would no longer count as a living religion. When money no longer operates as a medium of exchange, but coins have become collectors' items, it has changed its function. Similarly, religious festivals can become celebrations of other sorts, or temples and churches can be exploited as repositories for building materials or turned into places of heritage, and icons can be turned into art; they are still there but their function has changed into a nonreligious form. Finally, money is more than coins but is embedded into an economic system, which is in turn tied to cultural, ecological, legal, and political contexts. In the case of religion death, even if single items of a religion are transmitted to later generations, they are no longer part of an interlinked cluster (not to speak of an integrated system). In this sense, rather than a "survival," it has become a fragment. ${ }^{16}$

16 Several of these criteria resonate with observations on processes often subsumed under the general term "secularization"; yet, even if European forms of Christianity or Japanese forms of Buddhism are affected by such developments, these religions are not in imminent danger of extinction, even if their future destiny may look bleak. 
The articles published in this Numen special issue have resulted from our work at CAS. The case studies here are from the Mediterranean and adjacent regions: Samaria/Judea, Egypt, the Roman Empire, and Scandinavia. The articles deal with cases that have been subject to extensive debates, but the focus on demise opens new analytical perspectives. The endeavor is curiosity- and focus-driven rather than being informed by any overarching theory.

Damage or destruction of religious objects and places can occur in the context of warfare. Most often this is an accidental side effect, but it can also be intentional. The latter was maybe the case with the temples of Jerusalem. In 589 в Nebuchadnezzar II, King of Babylon, began a siege of the city of Jerusalem; eventually, the besiegers broke through the walls and conquered the city and Zedekiah was taken captive. Following the conquest of the city, a general was sent to complete the destruction of the city; in this context, in 587 (or 586 ) BCE the Temple of Solomon was destroyed (apparently by being set on fire; 2 Kings 23:9), and most of the elite were taken to Babylon into captivity. Only when the Persians conquered Babylon in 539 were the exiled allowed to return (but not all did). Eventually, a new temple was erected in Jerusalem around 516 , which was destroyed in $70 \mathrm{CE}$ by Roman legions following an insurrection in $66 \mathrm{CE}$.

The earlier traumatic triple event of collapse of a political structure, destruction of a city and a temple, and the abduction of the elite of the people was renarrated and rationalized in terms of a new theological scheme according to which the event was not really caused by the Babylonians but by their god Yahweh who thereby punished "his" people for their presumed prior negligence. This reversal of agency can also be observed with regard to religion demolition. For while the destruction of the temple of Jerusalem is mentioned in the Bible, Laura Feldt (2021; this issue) draws attention to two dramatic stories of religion demolition or imagined religiocide as narrated in two chapters of the two Biblical Books of Kings that both end with the violent murder of the prophets and priests of the allegedly ineffective and "wrong" gods (1 Kings 18:40; 2 Kings 23:20). Instead of taking these reports at face value, Feldt reads them as strategies to enhance the formation of group identity and to prevent decreasing commitment or even apostasy. From the present age, a similar interpretation seems valid for the horrendous acts of violence undertaken by Is: killing for a cause signals an extreme form of commitment, and doing so in a spectacularly ruthless manner even more so, and it makes it clear to everyone that apostates will be punished likewise. 
One of the most well-known dramatic religious changes from the ancient world occurred in ancient Egypt during the so-called Amarna-period (са. 1352-1295 ВСЕ). King Amenhotep, who changed his name to Akhenaten, built a new city in Middle Egypt, to which he moved with some 50,00o people and where the god of the visible sun (Aton) was worshiped - the name of this god also inspired his new name. While pre-Amarna gods are depicted in polymorph forms, the god at Amarna was depicted as the sun disk itself. Apparently, names and images of the god Amun, which informed his earlier throne-name, and partly also names of other gods, were deleted or removed throughout the realm (Quack 2019: 55-56). However, we have hardly any evidence for an erasure of an earlier form of religion; no temples were closed, no worshippers of other gods persecuted. In her contribution in this issue, Janne Arp-Neumann (2021), discusses a related case, that of the liminal, ambivalent or ambiguous, and disruptive deity Seth. While the fate of this god was recently presented as an example of "systematic persecution" (Quack 2019:59), Arp-Neumann provides a very different reading: by taking the material context into consideration, she reads the evidence for damage, chiseling out, stippling and other forms of modification as modes of ritually dealing with this powerful deity, rather than as examples of the annihilation of Seth. Instead of reading the transformation of Seth as an indicator of religious decay she proposes that it is evidence for the vitality of ancient Egyptian religion. ${ }^{17}$

As pointed out by Arp-Neumann, the spectacular ruins of Egyptian temples powerfully invoke the sensation of civilizational collapse. They vividly attest to the fact of religion death, even if they at the same time convey the memory of the existence of the former religion. The decay of temples is a prototypical index of the demise of a religion. Tales of temple-destruction are a trope in Christian triumphalist narratives; the destruction of the Serapeum at Alexandria in $392 \mathrm{CE}$ is one of the most well-known incidents. Yet, the archaeological evidence does not confirm the literary accounts that are typically found in hagiographical literature. Unambiguous cases of temple-destruction are exceptional; rather than as sites for symbolic action, temples were used to reclaim construction materials or they were used for other purposes like military camps, prison, or monasteries; in parts of some former Egyptian temples, churches were erected, others just remained dysfunctional. After all, following the Roman conquest, temple lands had been confiscated and new regulations made the priesthood less attractive. At the end of the 4th century, when the

17 Seth was sometimes depicted as the Canaanite god Bacal, and one can only speculate to what extent the destruction of this deity in 1 Kings 18 may have made some believe that Seth would have received similar treatment. 
Serapeum was destroyed and the temple cult was prohibited, many temples had already become dysfunctional and abandoned. The potential reuse of former temples for Christian purposes rarely amounted to any spectacular act, similar to our times, in Western Europe, where churches are reused as spaces for all sorts of cultural or commercial activities, or sometimes as mosques (the latter sometimes leading to concerns or protests)..$^{18}$

While Egyptian religion was not only about temples (and Christianity is not only about churches), the Asclepius (or the Perfect Discourse), a compilation probably from the early third century studied by Christian Bull (2021) in this issue, presents the temple cult as its essence. The text presents a precious insider-perspective on the demise of religion in the form of a lamentation by a retro-projected prophecy: instead of temples, the text predicts, the land will be full of tombs, the country will be abandoned by the gods and they will no longer be believed in - in "the old age of the gods," godlessness and infamy will rule. The text communicates a fatal threat of invasion and decay. But this process was not a linear one. Bull points to one source that attests that a certain Antonius, from a Neoplatonic school, had moved to Canobus not far from Alexandria, where he worshiped the Egyptian gods; apparently his presence led to a blossoming of ritual activities, and even visitors from abroad flocked to the place. Yet, this Antonius also predicted, as reported in a later source, that after his death the temple where he stayed would cease to exist and others would likewise face a gloomy future. Even here the idea of the temples as tombs is expressed. The violent destruction of pre-Christian sanctuaries is a trope in triumphalist Christian narratives, but Bull points to a case where such a story is corroborated by a non-Christian source, so these reports should not be dismissed as pure fantasy. Given the importance of the idea of the centrality of the temple for Egyptian religion, Bull suggests that the abandonment and destruction of temples might have paved the way for the appropriation of popular pre-Christian practices, which were no longer tied to the templereligion, by Egyptian Christians (Bull 2021; for the concept of appropriation as an alternative to Christianization, see Dijkstra 2021).

The Asclepius blames the decay of Egyptian religion on an invasion of foreigners, but these foreigners remain anonymous in the text. Just like in Egypt, where Neoplatonic philosophers had shown an interest in the resilience of the ancestral religion, it was a Platonic philosopher, Porphyry of Tyre who, in a work known as Contra Christianos written in the late third century CE, clearly articulated a sense of threat against the cultural, political, and religious order of Imperium Romanum constituted by the increasing spread and

18 On the fate of temples, mainly in Egypt, see Medini 2015; Dijkstra 2011; Grossmann 2008. 
self-consciousness of the Christians (Männlein-Robert 2017). Christians had even begun to invade the territory of Platonic philosophy. One episode mentioned by Porphyry serves to illustrate how the times had changed: when the city (Rome?) suffered an epidemic, there was no longer any expected arrival of Asclepius or any other deities; since Jesus was venerated nobody had perceived the public support of the gods (Becker 2017: 128). On this view, the old gods had become irrelevant or redundant; they had lost their effects and functions. The Roman Empire is one of the best studied examples of religious transformation - often described in the ambiguous and problematic processterm Christianization (see Leppin 2012 for a critical review). It is also a significant case, given the wide array of explicit, drastic, and ever more encompassing legal measures put into place against "paganism," but more so against so-called heretics, apostates, or Manichaeans (see Noethlichs 1986 for a chronological survey). Similar measures came to be applied throughout European history. The term pagani, which had replaced terms like gentes and gentiles became the main term for "non-Christians" from the mid-4th century onwards; it was "a relational concept, which means that it only exists in relation to, and in most cases, in contrast with, the concept of 'Christians'” (Kahlos 2020: 92); subsuming non-Christians under one category as an act of othering was a construction serving to control and conquer the religious field.

In this issue, two articles discuss the question of the demise or end of Graeco-Roman religions ("paganism"). Jörg Rüpke (2021) does not take the end of "paganism" as a given but moves the discussion to a reflexive level by inquiring about the presuppositions of talking about ends and the historiographical metaphors and tropes that are involved. He reminds us that we, as historians of religion, should not uncritically buy into ways religions describe their histories. Not only do we need to avoid false dichotomies (Christianity vs. Paganism, Jews vs. Christians etc.), but also Rüpke proposes to avoid talking about "religions" (and their "ends") altogether; instead, he wishes to break down the systematicity of these units to the four components of practices, beliefs, group formation, and institutionalization. This complicates any talk about ends as each of these categories comprises a cluster of things (such as sacrifice, vows, amulets, altars, etc. for practices) that each have their own histories with different degrees of discontinuities and continuities. These split histories do not coalesce into talking about the end of a religion - but if something has come to end, as also pointed out above, it was the structure of the religious field not premised on the existence of single and different religions. While Rüpke shows glimpses of the long durée of a complex of elements constituting a religious field through later European religious history, Jan Bremmer (2021) looks backward to the century before Constantine. In dialogue in particular 
with the works by Rüpke and James Rives, Bremmer seeks to identify religious developments in Graeco-Roman religion(s) that could explain what he calls its "silent demise," that is, the relatively peaceful transition to Christianity as the dominant and eventually hegemonic religion of the Roman Empire. Bremmer points to the emergence of various religious entrepreneurs, the expanding role of literacy and intellectual discourses, including the critique and rejection of animal sacrifice, and changes in the ways the gods were represented and the ways people related to their gods. According to Bremmer, Christians capitalized on these developments. He also takes into account some weaknesses of the traditional religion, for example in terms of professional organization, and some contingent circumstances such as the unusual longevity of Constantine's rule that provided his religious policy with a greater degree of sustainability.

An exceptional event of quasi-democratic and seemingly peaceful collective conversion events happened on Iceland in the symbolic year of $1000 \mathrm{CE}$. However, the process was clearly characterized by acts of verbal aggression and violence (Self 2010), and the fact that the decisive assembly (Althing) came together was the result of King Olaf in Norway having taken all Icelanders staying there as hostages. Initially, as the report in chapter VII of The Book of the Icelanders goes, there was no agreement in sight, as "each side, the Christians and the heathens, declared itself under separate laws from the other" (Grønlie 2006: 8). It is notable, here, that the two parties are presented as equal, that the non-Christians are classified as "heathens," and that the dividing line was not issues of beliefs, confessions, or practices, but separate "laws." Given the impasse, the Lawspeaker Thorgeir Thorkelsson, who at that time was a "heathen," was entrusted with the decision. In his initial statement he said "that he thought people's affairs had come to a bad pass, if they were not all to have the same law in this country." A little later he said: "let us all have the same law and the same religion [ein lög ok einn sið]. It will prove true that if we tear apart the law, we will also tear apart the peace." It was "then proclaimed in the laws that all people should be Christian, and that those who had not yet been baptised should be baptised." Some accommodations to the former laws were made, and people maintained the right "to sacrifice in secret," but "a few years later, these heathen provisions were abolished" (Grønlie 2006: 9). According to this account, the decision to convert was taken to safeguard the unity and peace of the people; one can speculate that Thorgeir must have realized that it was unrealistic to maintain the "heathen" law and to preserve peace given the ambitions of the king in Norway and the international power balance with its constant reinforcements (see Firth above) and the supremacy the Christian "law" had assumed in many relevant places. While it was a legal functionary who took the decision on behalf of the people on Iceland, the 
other Northern countries (Denmark, Norway, and Sweden) followed the topdown ruler conversion model. In his article, Olof Sundqvist (2021) discusses not only the Icelandic case, but also a case of violent destruction undertaken by a king in Trøndelag (Norway). Sundqvist analyzes the active role played by rulers in unwinding or erasing their previous religion. The first effective steps were the kings' refusal to assume their traditional roles in the public ritual gatherings, before proceeding to convince local chieftains and magnates to renounce their ancestral religion. Once they felt more secure in their position, ritual structures were destroyed or cultic places were transformed, and finally elements of the old religion were proscribed by legal means. The Christianity that had arrived in the North some centuries after it spread along the shores of the Mediterranean, had already assumed Germanic traits, so that it had at the same time become culturally somewhat familiar, yet still had a novel appeal. As Sundqvist points out, "Christianization" has been a key-term in studies of religious change in the North, in similar ways to how it is used in research on Egypt and the Roman Empire. Sundqvist notes that the Christian converts played on "vulnerable areas" (what Bremmer would call "weaknesses") of the traditional religious culture, in particular the lack of independent priestly institutions and authoritative religious writings.

\section{1 \\ Conclusion}

While we may take the fact of religion death (i.e., the existence of dead religions) for granted, the articles in this special issue have looked at the processes leading to the demise of ancient/traditional religions. As we have seen, there are some sources that show interested actors and participants who were conscious of witnessing crucial historical changes, some lamenting a monumental loss, some in a triumphalist mode, others assessing advantages and disadvantages of substituting the extant religion. Calling a religion extinct can serve as an interested appellation and not as an unambiguous statement of facts. Far from being an automatic or unconscious process of abandoning and forgetting, in many cases the dissolution of religions (or religious cultures) was actively promoted, with different degrees and forms of violence. We have seen that sources that can be interpreted as evidence for decline can also be read quite differently, for example as indices of religious vitality or of strategies of identity affirmation. In such processes, the roles of outsiders and insiders are not always easy to distinguish. Since religions appear as complex, composite, or even hybrid configurations, continuities and discontinuities or ends can 
occur in different temporalities; typically, there is no clear point of ending (but see the case described by Robbins for an exception). In some cases, we can speak of a rotational transformation that involves the slow transition from one type of religion to another, from implicit to explicit forms of religion. Until the 2oth century, rulers (kings) played a decisive role in religious transitions, sometimes actively intervening in the dissolution of a former religion. Personal persuasions (conversions) aside, rulers (kings) typically decided to opt for religious change in the hope of boosting their own standing and status. In the Judaean case, however, it seems that narratives about violent religious demolition were crafted in the aftermath of the loss of kingship; yet, whereas the king is absent in one of the narratives (1 Kings 18), in the second story (2 Kings 23) it is a king (Josiah) who purportedly went about to actively and aggressively dismantle instances of religion unrelated to the powerful deity the narrative seeks to promote.

In an antiquarian mode, history of religions as an academic field seeks to salvage traces of extinct religious traditions (or of religious traditions that are likely to fade away). In a (source) critical mode, we know that there are no facts that are independent of interests and representations. That does not mean that we cannot take a position. For example, the attempted religiocide undertaken by IS in 2014 is represented as sacred duty and a matter of pride and triumph in Is publications, whereas the victims and the world at large have perceived it as a horrible tragedy. While we recognize that there are interests, values, and narratives at work on both sides, as humans, I assume, historians of religion would feel a sense of shock and disgust and we would sympathize with the victims. The reports do not leave us unaffected and neutral. Yet, would we, as a matter of principle, tend to sympathize with the "losers" of history, especially when this change is imposed by interested parties with uneven power balances, or when the change is enforced by various means of violence or enforced by discriminating legislation? Do we have a bias toward the underprivileged, the disadvantaged, outcasts, stigmatized, and minorities? Do we consider it our professional duty to represent their cases and keep their religion alive in cultural memory? Yet, it would hardly seem fair and correct to compare the fate of the Yezidis with the Egyptians, Romans, or Icelanders. After all, the use of violence was not pervasive, the process of transformation was much more complicated and long, and Egyptians, Romans, and Icelanders actively departed from their traditional religions; affirming a new religion provided new material, political, social, and spiritual opportunities. The case might be different for the worshippers of Ba'al whose suppression and murder the authors of the Biblical First Book of Kings fantasize about - even if this did not reflect any 
actual happening, the very fantasy and its transmission in an authoritative writing is scary in its brutality.

This special issue seeks to overcome an endemic focus on origins and the ordinary range of religious change by employing a different narrative and metaphorical register - that of ends, demise, elimination, etc. The increasing attention to phenomena of extinction calls for scholars from the humanities to propose context-sensitive analytic accounts of the theme of ends and endings, for example in religious history.

\section{Acknowledgments}

This article was written as part of the project "The Demise of Religions" (201819) at the Centre for Advanced Study (CAS) in Oslo, Norway. I wish to thank CAS (the director and the staff) for providing excellent conditions for work and life in Oslo. CAS also sponsored Open Access publication of this special issue. Thanks to Laura Feldt and Anders Klostergaard Petersen for close and critical reading of an earlier draft and to Laura Feldt for her careful editorial eye.

\section{References}

Alles, Gregory D. 2012. "Kinds, Classes, and Clumps: A Preliminary Typology of Concepts and some Implications for the Study of Religions." Studies in Religion/ Sciences Religieuses 41 (1): 12-23. doi: 10.1177/ooo8429811430054.

Arp-Neumann, Janne. 2021. "Negating Seth: Destruction as Vitality." Numen 68(2-3): 157-179.

Becker, Matthias. 2016. Porphyrios, Contra Christianos: Neue Sammlung der Fragmente, Testimonien und Dubia mit Einleitung, Übersetzung und Anmerkungen. Berlin: de Gruyter.

Becker, Matthias. 2017. "Polemik, Bedrohungskommunikation, Emotion: Porphyrios und sein Umgang mit der christlichen Bedrohung in Contra Christianos." In I. Männlein-Robert (ed.), Die Christen als Bedrohung? Text, Kontext und Wirkung von Porphyrios' Contra Christianos, Stuttgart: Steiner, 111-135.

Bellah, Robert Neelly. 2011. Religion in Human Evolution: From the Paleolithic to the Axial Age. Cambridge, MA: Belknap Press of Harvard University Press.

Berkwitz, Stephen C. 2010. South Asian Buddhism: A Survey. London: Routledge.

Bremmer, Jan N. 2021. "How Do We Explain the Quiet Demise of Graeco-Roman Religion: An Essay." Numen 68(2-3): 230-271. 
Bull, Christian H. 2021. "Prophesying the Demise of Egyptian Religion in Late Antiquity: The Perfect Discourse and Antoninus in Canopus." Numen 68(2-3): 180-203.

Cheterian, Vicken. 2019. "ISIS Genocide against the Yazidis and Mass Violence in the Middle East." British Journal of Middle Eastern Studies: 1-13. doi: 10.1080/13530194.2019.1683718.

Colpe, Carsten. 1986. “Was bedeutet 'Untergang einer Religion'?” In Hartmut Zinser (ed.), Der Untergang von Religionen, Berlin: Reimer, 9-33.

Cusack, Carole M. 2013. "Enlightenment Concepts, Medieval Contexts." In James L. Cox (ed.), Critical Reflections on Indigenous Religions, Farnham: Ashgate, 65-80.

Diamond, Jared M. 2005. Collapse: How Societies Choose to Sail or Succeed. New York: Viking.

Dijkstra, Jitse H. F. 2011. "The Fate of the Temples in Late Antique Egypt." In Luke Lavan and Michael Mulryan (eds.), The Archaeology of Late Antique "Paganism," Leiden: Brill, $389-436$.

Dijkstra, Jitse H. F. 2021. "Appropriation: A New Approach to Religious Transformation in Late Antiquity." Numen 68(1): 1-38. doi:1163/15685276-12341610.

Dreher, Rod. 2011. "Bellah: 'Nothing Is Ever Lost." The American Conservative, 1o October. URL: https://www.theamericanconservative.com/dreher/bellah-nothing-is-ever -lost/.

Engelke, Matthew. 2010. "Past Pentecostalism: Notes on Rupture, Realignment, and Everyday Life in Pentecostal and African Independent Churches." Africa 8o(2): 177199. doi: 10.3366/afr.2010.0201.

Engler, Steven. 2016. "Why be Critical?" Religion 46(3): 412-419. doi: 10.1080/004 8721X.2016.1192831.

Ernst, Manfred. 2012. "Changing Christianity in Oceania:A Regional Overview." Archives de sciences sociales des religions 157: 29-45. doi: https://doi.org/10.400o/assr.23613.

Feldt, Laura. 2020. "Total Devotion: Dismantling Religious Practices and Training Devotion in 2 Kings 22-23." Journal for the Study of Judaism 51: 309-338.

Feldt, Laura. 2021. "Destruction, Death, and Drama: Narratives of Religiocide in the Hebrew Bible." Numen 68(2-3): 132-156.

Firth, Raymond. 1970. Rank and Religion in Tikopia: A Study in Polynesian Paganism and Conversion to Christianity. London: George Allen and Unwin.

Fox, Jonathan. 2016. The Unfree Exercise of Religion: A World Survey of Discrimination against Religious Minorities. Cambridge: Cambridge University Press.

Fox, Jonathan. 2020. Thou Shalt Have No Other Gods before Me: Why Governments Discriminate against Religious Minorities. Cambridge: Cambridge University Press.

Frankfurter, David. 2018. Christianizing Egypt: Syncretism and Local Worlds in Late Antiquity. Princeton, NJ: Princeton University Press.

Gallaher, Carolyn. 2007. "The Role of Protestant Missionaires in Mexico's Indigenous Awakening." Bulletin of Latin American Research 26(1): 88-111. 
Gilhus, Ingvid Sælid. 2014. "Founding Fathers, Turtles and the Elephant in the Room: The Quest for Origins in the Scientific Study of Religion." Temenos 50(2): 193-214.

Grønlie, Siân (trans.). 2006. Íslendingabók, Kristni Saga. The Book of the Icelanders. The Story of the Conversion. London: Viking Society for Northern Research / University College London.

Grossmann, Peter. 2008. "Modalitäten der Zerstörung und Christianisierung pharaonischer Tempelanlagen." In Johannes Hahn, Stephen Emmel, and Ulrich Gotter (eds.), From Temple to Church: Destruction and Renewal of Local Cultic Topography in Late Antiquity, Leiden: Brill, 299-334.

Gruber, Jacob W. 1970. "Ethnographic Salvage and the Shaping of Anthropology." American Anthropologist 72(6): 1289-1299. doi: 10.1525/aa.1970.72.6.02a0oo4o.

Hubai, Peter. 2001. "Über die Ursachen des Sieges des Christentums in Ägypten." Numen 48(1): 81-116.

Isakhan, Benjamin, and José Antonio González Zarandona. 2018. "Layers of Religious and Political Iconoclasm under the Islamic State: Symbolic Sectarianism and Pre-Monotheistic Iconoclasm." International Journal of Heritage Studies 24 (1): 1-16. doi: 10.108 o/13527258.2017.1325769.

de Jong, Albert. 2016. "The Disintegration and Death of Religions." In Michael Stausberg and Steven Engler (eds.), The Oxford Handbook of the Study of Religion, Oxford: Oxford University Press, 646-664.

Kahlos, Maijastina. 2020. Religious Dissent in Late Antiquity, 350-45o. New York: Oxford University Press.

Klimkeit, Hans-Joachim. 1986. "Der Untergang des Manichäismus in West und Ost." In Hartmut Zinser (ed.), Der Untergang von Religionen, Berlin: Reimer, 113-125.

Kohl, Karl-Heinz. 1986. "Religiöser Partikularismus und kulturelle Transzendenz. Über den Untergang von Stammesreligionen in Indonesien." In Hartmut Zinser (ed.), Der Untergang von Religionen, Berlin: Reimer, 193-220.

Krech, Volkhard. 2012. "Religious Contacts in Past and Present Times: Aspects of a Research Programme.” Religion 42(2): 191-213. doi:10.1080/0048721X.2012.642572.

Leppin, Hartmut. 2012. "Christianisierungen im Römischen Reich: Überlegungen zum Begriff und zur Phasenbildung." Zeitschrift für Antikes Christentum / Journal of Ancient Christianity 16(2): 247-278. doi: 10.1515/zac-2012-0016.

Lim, Richard. 2019. "The Demise of Manichaeism in the Roman Mediterranean: Some Comparative Approaches and Perspectives." cas, internal paper, June.

Luhmann, Niklas. 1977. Funktion der Religion. Frankfurt am Main: Suhrkamp.

Männlein-Robert, Irmgard (ed.). 2017. Die Christen als Bedrohung? Text, Kontext und Wirkung von Porphyrios' “Contra Christianos.” Stuttgart: Franz Steiner Verlag.

Medini, Lorenzo. 2015. “Chronique d'une mort annoncée? Le crépuscule des temples et des païens d'Égypte.” Topoi 20: 239-28o. 
Meyer, Birgit. 1998. "Make a Complete Break with the Past': Memory and Post-Colonial Modernity in Ghanaian Pentecostalist Discourse." Journal of Religion in Africa 28(3): 316-349. doi: 10.2307/1581573.

Miller, Timothy. 2010. "The Evolution of American Spiritual Communities, 1965-2009." Nova Religio: The Journal of Alternative and Emergent Religions 13(3): 14-33. doi: 10.1525/nr.2010.13.3.14.

Monberg, Torben. 1962. "Crisis and Mass Conversion on Rennell Island in 1938." The Journal of the Polynesian Society 71(2): 145-150.

Monberg, Torben. 1991. Bellona Island Beliefs and Rituals. Honolulu: University of Hawai'i Press.

Montero Herrero, Santiago, and Diego M. Escámez De Vera. 2017. "Minorities and Divination Practices in the Roman Empire." Studi e Materiali di Storia delle Religioni 83(2): 333-342.

Noethlichs, Karl Leo. 1986. "Heidenverfolgung." In Theodor Klauser, Ernst Dassmann, Carsten Colpe, Albrecht Dihle, Josef Engmann, Bernhard Kötting, Wolfgang Speyer, Klaus Thraede, and Jan Hendrik Waszink (eds.), Reallexikon für Antike und Christentum: Sachwörterbuch zur Auseinandersetzung des Christentums mit der Antiken Welt. Stuttgart: Anton Hiersemann, vol. 13, 1149-119o.

Paldam, Ella. 2017. "Chumash Conversions: The Historical Dynamics of Religious Change in Native California." Numen 64(5-6): 596-625. doi: https://doi.org/10.1163/ 15685276-12341482.

Pew. 2010. Tolerance and Tension: Islam and Christianity in Sub-Saharan Africa. Washington, DC: Pew Research Center's Forum on Religion \& Public Life.

Pratt, James Bissett. 1921. “Why Do Religions Die?” The Journal of Religion 1(1): 76-78.

Quack, Joachim Friedrich. 2019. “'Lösche seinen Namen aus!' Zur Vernichtung von personenreferenzierter Schrift und Bild im Alten Ägypten.” In Carina Kühne-Wespi, Klaus Oschema, and Joachim Friedrich Quack (eds.), Zerstörung von Geschriebenem: Historische und transkulturelle Perspektiven, Berlin: de Gruyter, 43-119.

Robbins, Joel. 2014. "How Do Religions End? Theorizing Religious Traditions from the Point of View of How They Disappear." The Cambridge Journal of Anthropology 32(2): 2-15.

Rollinger, Robert. 2017. "Haruspicy from the Ancient Near East to Etruria." In Alessandro Naso (ed.), Etruscology, Boston: de Gruyter, 341-355.

Rothstein, Mikael. 2016. Regnskovens religion: forestillinger og ritualer blandt Borneos sidste jæeger-samlere - En religionshistorisk monografi. Copenhagen: U Press.

Rüpke, Jörg. 2021. "What Comes to an End when a 'Religion' Comes to an 'End'? Reflections on a Historiographical Trope and Ancient Mediterranean History of Religion." Numen 68(2-3): 204-229.

Rydving, Håkan. 1995. The End of Drum-Time: Religious Change among the Lule Saami, 1670s-1740s. 2nd ed. Stockholm: Almqvist \& Wiksell International. 
Savucu, Halil. 2016. Yeziden in Deutschland: Eine Religionsgemeinschaft zwischen Tradition, Integration und Assimilation. Marburg: Tectum.

Schilbrack, Kevin. 2010. "Religions: Are There Any?" Journal of the American Academy of Religion 78(4): 1112-1138. doi: 10.1093/jaarel/lfqo86.

Schneider, Nathan. 2011. "Nothing is Ever Lost: An Interview with Robert Bellah." The Immanent Frame, 14 September. URL: http://tif.ssrc.org/2011/o9/14/nothing -is-ever-lost/.

Self, Kathleen M. 2010. "Remembering our Violent Conversion: Conflict in the Icelandic Conversion Narrative." Religion 43(3):182-192. doi: 10.1016/j.religion.2009.10.011.

Sinhababu, Supriya. 20o8. "Interview with J. Z. Smith.” The Chicago Maroon, 2 June. URL: https:/www.chicagomaroon.com/2008/o6/o2/interview-with-j-z-smith/.

Smith, Jonathan Z. 1982. Imagining Religion: From Babylon to Jonestown. Chicago: University of Chicago Press.

Stausberg, Michael. 20og. "Renaissancen: Vermittlungsformen des Paganen." In Hans G. Kippenberg, Jörg Rüpke, and Kocku von Stuckrad (eds.), Europäische Religionsgeschichte: Ein mehrfacher Pluralismus, 2 vols., Göttingen: Vandenhoeck \& Ruprecht, vol. 1, 695-722.

Stausberg, Michael. 2019. "Endangered Religions." Opening keynote lecture at the 2019 European Association for the Study of Religions conference, June 25, Tartu. URL: https://www.academia.edu/41791295/Endangered_religions.

Stausberg, Michael, Stuart A. Wright, and Carole M. Cusack (eds.). 2020. The Demise of Religion: How Religions End, Die, or Dissipate. London: Bloomsbury Academic.

Stausberg, Michael, and Steven Engler. 2016. "Theories of Religion." In Michael Stausberg and Steven Engler (eds.), The Oxford Handbook of the Study of Religion, Oxford: Oxford University Press, 52-72.

Strathern, Alan. 2017. "Global Patterns of Ruler Conversion to Islam and the Logic of Empirical Religiosity." In A. C. S. Peacock (ed.), Islamisation: Comparative Perspectives from History, Edinburgh: Edinburgh University Press, 21-55.

Strathern, Alan. 2019. Unearthly Powers: Religious and Political Change in World History. Cambridge: Cambridge University Press.

Sundqvist, Olof. 2021. "The Role of Rulers in the Winding Up of the Old Norse Religion." Numen 68(2-3): 272-297.

Taves, Ann. 20o9. Religious Experience Reconsidered: A Building-Block Approach to the Study of Religion and Other Special Things. Princeton, NJ: Princeton University Press.

Tweed, Thomas A. 2006. Crossing and Dwelling: A Theory of Religion. Cambridge, MA: Harvard University Press.

UN General Assembly. 1948. Convention on the Prevention and Punishment of the Crime of Genocide, 9 December. URL: https://www.ohchr.org/en/professionalinter est/pages/crimeofgenocide.aspx. 
Vilaça, Aparecida. 2014. "What if a Religion Is Not Made to Last?" The Cambridge Journal of Anthropology 32(2):16-18.

Wagner, Andreas (ed.). 2006. Primäre und sekundäre Religion als Kategorie der Religionsgeschichte des Alten Testaments. Berlin: de Gruyter.

Watts,Joseph, OliverSheehan, Joseph Bulbulia, Russell D. Gray, and Quentin D. Atkinson. 2018. "Christianity Spread Faster in Small, Politically Structured Societies." Nature Human Behaviour 2(8): 559-564. doi: 10.1038/s41562-018-o379-3.

Weitzman, Steven P. 2005. Surviving Sacrilege: Cultural Persistence in Jewish Antiquity. Cambridge, MA: Harvard University Press.

Wilson, Bryan R. 1987. "Factors in the Failure of New Religious Movements." In David G. Bromley and Phillip E. Hammond (eds.), The Future of New Religious Movements, Macon, GA: Mercer University Press, 30-45.

Wilson, David Sloan. 2002. Darwin's Cathedral: Evolution, Religion, and the Nature of Society. Chicago: University of Chicago Press.

Wright, Stuart A., Michael Stausberg, and Carole M. Cusack. 2020. "How Religions End: Terms and Types." In Michael Stausberg, Stuart A. Wright, and Carole M. Cusack (eds.), The Demise of Religion: How Religions End, Die, or Dissipate, London: Bloomsbury Academic, 13-30.

Zinser, Hartmut (ed.). 1986. Der Untergang von Religionen. Berlin: Dietrich Reimer. 